\title{
MINERAL RESOURCE POTENTIAL OF THE SANGRE DE CRISTO WILDERNESS STUDY AREA, SOUTH-CENTRAL COLORADO
}

\author{
By \\ Bruce R. Johnson and David A. Lindsey, U.S. Geological Survey \\ and \\ Clarence E. Ellis, Brian J. Hannigan, and John R. Thompson, U.S. Bureau of Mines
}

\section{STUDIES RELATED TO WILDERNESS}

Under the provisions of the Wilderness Act (Public Law 88-577, September 3, 1964) and related acts, the U.S. Geological Survey and the U.S. Bureau of Mines have been conducting mineral surveys of wilderness and primitive areas. Areas officially designated as "wilderness," "wild," or "canoe" when the act was passed were incorporated into the National Wilderness Preservation System, and some of them are presently being studied. The act provides that areas under consideration for wilderness designation should be studied for suitability for incorporation into the Wilderness System. The mineral surveys constitute one aspect of the suitability studies. The act directs that the results of such surveys are to be made available to the public and be submitted to the President and the Congress. This report discusses the results of a mineral survey of the Sangre de Cristo Wilderness Study Area, Rio Grande and San Isabel National Forests, Fremont, Saguache, Custer, Huerfano, Alamosa, and Costilla Counties, south-central Colorado. The area was designated as a wilderness study area under Public Law 96-560 in 1980.

\section{MINERAL RESOURCE POTENTIAL SUMMARY STATEMENT}

Mineral surveys undertaken largely in 1981 and 1982 delineated an area of low to moderate mineral resource potential, an area of moderate mineral resource potential, and an area of high mineral resource potential in the Sangre de Cristo Wilderness Study Area (also referred to as the WSA or the study area). An area of moderate mineral resource potential for gold, silver, and base metals lies along a northwest structural trend which follows the western margin of the Sangre de Cristo Range north of the Great Sand Dunes National Monument and crosses the range south of the monument. Known deposits are dominantly gold- and silver-bearing veins with less common occurrences of base metals. An area of high mineral resource potential for gold and silver in similar veins has been identified near Blanca Peak at the extreme southern end of the WSA. Veins in this area contain tungsten in addition to base and precious metals. Finally, an area of low to moderate resource potential for molybdenum has been identified in rocks associated with the Rito Alto stock at Cloverdale Basin in the eastcentral part of the WSA.

\section{INTRODUCTION}

The Sangre de Cristo Wilderness Study Area includes approximately 250,000 acres of the main Sangre de Cristo Range in south-central Colorado from about $7 \mathrm{mi}$ south of Salida south to Blanca Peak (fig. 1). The WSA is approximately $70 \mathrm{mi}$ long and averages 5-8 mi wide. The boundary generally follows the foot of the mountains except where it deviates around private land or roads. The WSA is partially bordered on the west by the Luis Maria Baca No. 4 land grant and by the Great Sand Dunes National Monument. The eastern boundary follows the Rainbow Trail for much of its length. The portion of the WSA west of the range crest lies in the Rio Grande National Forest; the portion east of the crest lies in the San Isabel National Forest. The town of Westcliffe is about $7 \mathrm{mi}$ east of the center of the WSA, Alamosa is about $15 \mathrm{mi}$ south- west of the southern end, and Salida is about $7 \mathrm{mi}$ north of the northern end.

Access is generally excellent for foot travel, with most drainages containing good trails into the high parts of the range. Four-wheel-drive roads cross the range at Hayden Pass on the north and at Medano Pass to the south. Several other dirt roads are the cause of reentrants into the study area at Lake Creek, Middle Taylor Creek, North and South Crestone Creeks, South Colony Creek, and Music Pass. Elevation ranges from 14,363 ft at Blanca Peak to about $8,000 \mathrm{ft}$ along the southwestern boundary. Several 14,000-ft peaks and numerous 13,000-ft peaks form the crest of the range for most of the length of the study area. Many of the high peaks are extremely rugged and, particularly in the vicinity of Crestone Peak, loose rock makes foot travel hazardous. 


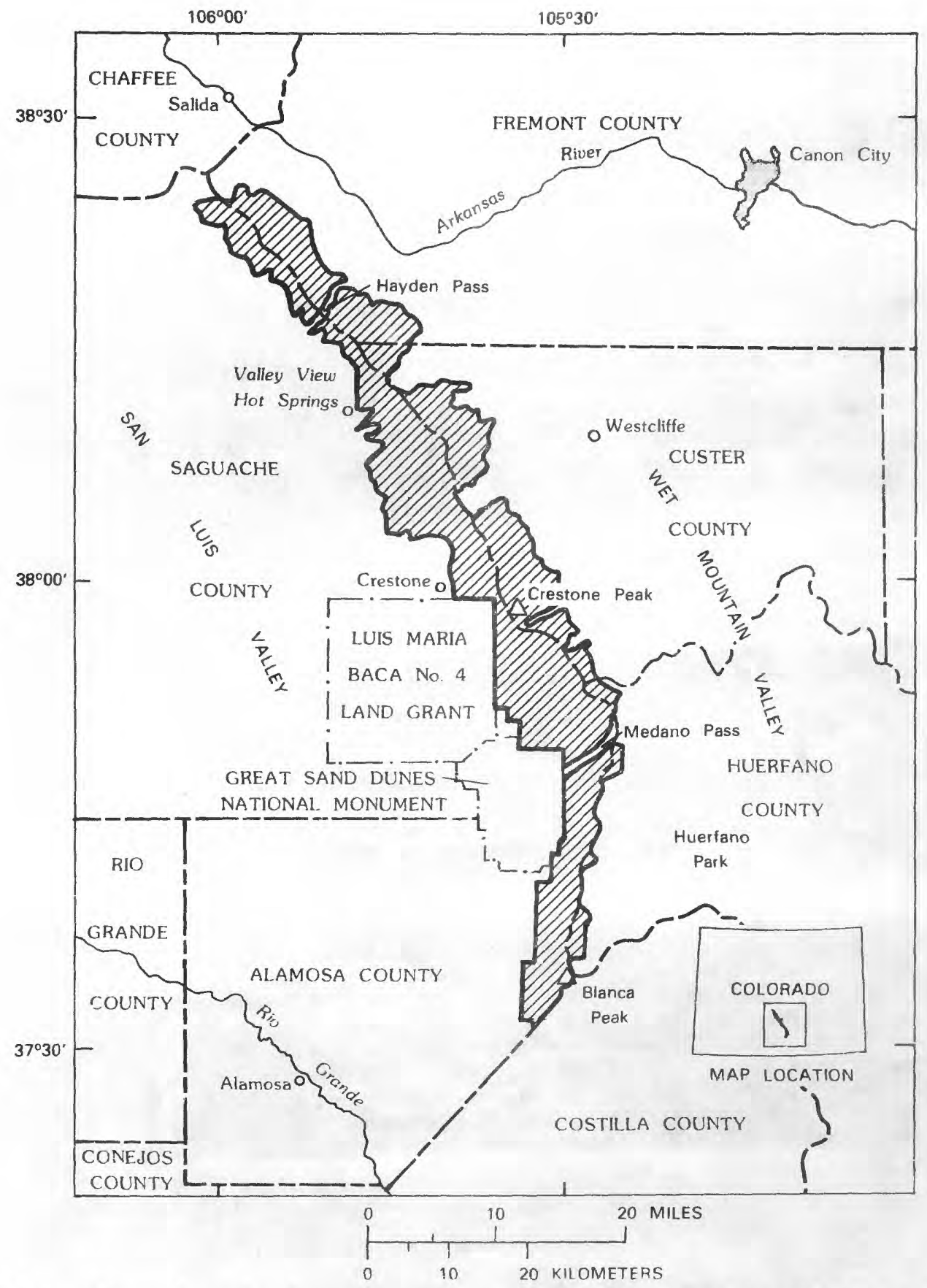

Figure 1.--Map showing location of Sangre de Cristo Wilderness Study Area (diagonally ruled), Colorado. 


\section{GEOLOGY}

\section{Rock units}

Most of the rocks exposed in the WSA are either Precambrian crystalline rocks or upper Paleozoic clastic sedimentary rocks. In addition, several faultbounded slivers of lower Paleozoic sedimentary rock occur within the Precambrian rocks near the western boundary of the study area. A thin sequence of lower Paleozoic sedimentary rocks also occurs locally between Precambrian rocks and upper Paleozoic sedimentary rocks. Small patches of Jurassic sedimentary rocks and Tertiary volcanic and sedimentary rocks crop out along the eastern and northeastern boundaries of the study area. The WSA also contains several small granitic stocks of Tertiary age and numerous dikes and sills, mostly of Tertiary age. A more detailed map and description of the geology can be found in Johnson and others (1984).

The Precambrian crystalline rocks are composed of several gneissic units which have been intruded by Precambrian igneous bodies of various sizes. A heterogeneous package of banded mafic and felsic gneissic rocks dominated by biotite-quartzplagioclase-microcline gneiss interlayered with quartzplagioclase-hornblende gneiss occurs along the western side of the study area for most of its length. In the north, the gneissic package grades northeastward into a silicic, muscovite-bearing gneiss with distinctive quartz-augen porphyroblasts. Both units are intruded by several large bodies of hornblende metadiorite. At the south end of the WSA, the heterogeneous gneiss package is joined by laminated plagioclase-hornblende gneiss; both units are intruded by a large body of leucocratic, gneissic tonalite and several bodies of hornblende metadiorite. A small sliver of Precambrian quartzite breccia occurs near the eastern boundary of the WSA. All of the gneissic units are intruded by later, weakly foliated to nonfoliated granitic rocks ranging from dikes several inches thick to plutons several miles across.

Although small massive sulfide lenses may have escaped detection due to the reconnaissance nature of this study, little evidence was found for Precambrian mineralization in the gneissic rocks of the WSA. No mineral occurrences have been found associated with the Precambrian plutonic rocks in the area except minor, local, disseminated sulfide minerals (pyrite, chalcopyrite, and pyrrhotite?) within the metadiorite near Blanca Peak.

Sedimentary rocks of early Paleozoic age crop out along the west side of the range from the Great Sand Dunes northward to Hayden Pass, where they cross to the east side of the range. From the Sand Dunes to Valley View Hot Springs, most of the lower Paleozoic rocks occur in strips bounded partly by faults; northward from Valley View Hot Springs, the lower Paleozoic rocks occur in normal stratigraphic sequence above Precambrian rocks and below upper Paleozoic rocks. In ascending stratigraphic order, the lower Paleozoic rocks consist of Ordovician Manitou Limestone, Ordovician Harding Sandstone, Ordovician Fremont Dolomite, Devonian to Mississippian Chaffee Group, and Mississippian Leadville Limestone; the entire thickness of lower Paleozoic strata is less than $400 \mathrm{ft}$. The calcareous composition of many of the lower Paleozoic rocks make them an ideal host for base-metal replacement deposits such as the iron deposit at the Orient mine.

Thick formations of mostly sandstone, conglomerate, and shale of late Paleozoic age crop out over much of the central and northern part of the WSA. Upper Paleozoic rocks consist of as much as $6,000 \mathrm{ft}$ of Pennsylvanian Minturn Formation and as much as 6,000 ft of Pennsylvanian and Permian Sangre de Cristo Formation. Most of the Sangre de Cristo Formation is red; the redbeds overlie an interval of calcareous beds in the lowermost part of the Sangre de Cristo Formation and the upper part of the Minturn that contains numerous, small, mineralized lenses having anomalous concentrations of copper and uranium. All of the Precambrian and Paleozoic rocks are locally intruded by Tertiary dikes which range from granitic to basaltic in composition. Two Tertiary granitic plutons are exposed within the study area, the Rito Alto stock and the Slide Rock Mountain stock.

Younger formations also crop out along the flanks of the range. Thin-bedded sandstone, shale, and limestone of Jurassic age crop out in a syncline at Loco Hill, east of the WSA. Basalt flows crop out from Crystal Creek south to Middle Bruff Creek west of Huerfano Park (fig. 1). Volcaniclastic sediments, volcanic flow rocks, and tuffs crop out in an Oligocene paleovalley at Goat Creek, and similar rocks of Oligocene and Miocene age crop out along the Arkansas River Valley north of the study area. Valleys are underlain by Miocene and younger sediments and volcanic rocks. Glacial and alluvial deposits of late Miocene to Holocene age cover the lower slopes of the range and some valley floors in the range.

\section{Structure}

The Precambrian and Paleozoic rocks of the WSA have been folded and thrusted in Laramide time (Late Cretaceous to Eocene; Lindsey and others, 1983), so that the central part of the study area is traversed by northwest-trending thrust faults. The thrusts are part of a large thrust zone that extends from New Mexico northward along the east side of the Uncompahgre-San Luis uplift of Laramide age. Beginning in late Oligocene time, the opening of the Rio Grande rift cut across the pattern of Laramide compressional structures. The horst of the Sangre de Cristo Range was uplifted at this time, and the San Luis and Wet Mountain Valleys downdropped by extensional rift faulting so that Laramide structures are exposed intact in the central part of the range but are covered by Miocene and younger sediments in the adjacent valleys.

Most of the Laramide thrust faults in the WSA lie in a northwesterly trending zone that extends across the range from Valley View Hot Springs on the west to Huerfano Park on the east. All of the thrust faults within this zone dip west at angles ranging from about $35^{\circ}$ to nearly vertical and cut Mesozoic and Paleozoic sedimentary rocks and Precambrian crystalline rocks. The thrust faults are interpreted to flatten with depth. The thrust plates are internally folded; the folds tighten and decrease in amplitude toward the leading edge of each plate. Total shortening within the range is estimated at approximately $5 \mathrm{mi}$ at the latitude of Westcliffe and about $8 \mathrm{mi}$ further south near the latitude of the Great Sand Dunes National Monument. Along the east side of the range, the 
Alvarado fault is interpreted tentatively to have acted as an east-dipping thrust during Laramide compression, bringing Precambrian crystalline rocks west over Paleozoic rocks. Southwest of the main thrust zone, Precambrian crystalline rocks west of Mosca Pass and north and east of Blanca Peak are cut by a thrust complex which includes slices of upper Paleozoic sedimentary rocks.

Much of the Sangre de Cristo Range in the study area is bounded by two large normal faults; the Sangre de Cristo fault extends along most of the west side of the range and the reactivated Alvarado fault extends along the north half of the range on the east. These range-front faults formed in response to extensional rifting that uplifted the Sangre de Cristo Range and downdropped the adjacent valleys. Rifting and attendant uplift of the range probably began in late Oligocene time, proceeded rapidly at intervals beginning in early Miocene time, and continues today. The cumulative movement along the range-front faults is such that the floor of the Miocene and younger sedimentary and volcanic fill of the San Luis Valley is as much as $20,000 \mathrm{ft}$ below the top of the range and the floor of the Wet Mountain Valley fill is about 6,000 ft below the top of the range.

\section{GEOCHEMISTRY}

\section{Stream-sediment anomalies}

During the summer of 1982 , stream-sediment samples were collected from first- and second-order stream drainages. For each sample locality a pannedconcentrate sample and a minus-80-mesh sample were analyzed. Each panned-concentrate sample represents a composite collection of stream sediment panned in the field with a 16-in. gold pan to an approximate composition of half dark minerals and half light minerals. All samples were analyzed semiquantitatively for 31 elements using a six-step, direct-current arc, optical-emmission, spectrographic method (Grimes and Marranzino, 1968). Of the 31 elements in the analysis, beryllium, bismuth, cadmium, copper, lead, molybdenum, silver, tin, tungsten, and zinc represent metals of potential economic interest or may be indicators of potential economic mineralization in the study area and occur above their detection limits in enough samples to show a range from background to potentially anomalous levels. The discussion of geochemically anomalous areas which follows is based on contour maps plotted for each of these elements (D. R. Zimbelman, written commun., 1983). Samples were identified as anomalous on these maps if the analytical value for a given element exceeded approximately the 90 th percentile of all analyses. Boundaries of geochemically anomalous areas based on stream-sediment samples are uncertain because each sample represents the entire drainage basin upstream from the sample site. Three areas contain anomalous amounts of the elements considered here and are informally referred to as the Bushnell Peak area, the western margin-Carbonate Mountain area, and the Blanca Peak area (figs. 2A, B).

The Bushnell Peak anomalous area includes much of the northwest end of the WSA north of Hayden Pass (fig. 2A). Copper, lead, tin, tungsten, and zinc occur in anomalous amounts throughout the Bushnell Peak area. Samples anomalous in molybdenum are common at the southern end of the anomalous area and scattered samples anomalous in beryllium, bismuth, and cadmium occur throughout the area. There are several possible sources of mineralization in the Bushnell Peak area. The geochemical anomaly may be caused by sparse, base-metal-bearing quartz veins, particularly west of the divide in the Raspberry Creek mineralized area, described below. The occurrence of tin and tungsten in panned-concentrate samples is similar to the geochemical signature of Precambrian massive sulfide deposits which occur within the Pueblo $1^{\circ} \times 2^{\circ}$ quadrangle, north of the study area (R. B. Taylor, oral commun,, 1983). These deposits are typically small and difficult to identify, and no evidence was found of massive sulfide deposits during this reconnaissance study. Finally, the Sangre de Cristo fault extends into this area so that mineralization associated with it, as described below, may also contribute to the anomaly in the Bushnell Peak area.

Scattered geochemical anomalies occur along the western margin of the study area from the Hayden Pass road to the Great Sand Dunes National Monument and cross the range near Carbonate Mountain (figs. $2 \mathrm{~A}$, B). The strongest anomalies within this belt include concentrations of copper, lead, molybdenum, tin, and tungsten along Black Canyon; cadmium, copper, lead, and zinc along Cotton Creek; copper, lead, molybdenum, and tin along Crestone Creek; cadmium, copper, lead, and zinc along Spanish Creek; a large area of anomalous copper, lead, molybdenum, tin, and tungsten with scattered anomalous cadmium and zinc which includes Cottonwood Creek and Deadman Creek; and a large area of anomalous beryllium, cadmium, tin, tungsten, and zinc in the vicinity of Carbonate Mountain. Most of the other drainages in the anomalous area also contain sparse anomalous samples.

The western margin-Carbonate Mountain anomalous area is roughly coincident with the outcrop area of Precambrian rocks along the western margin of the WSA and thus may be merely an indication of higher background levels of metallic elements in the gneissic rocks than in the Paleozoic sediments. However, there are several areas of Precambrian gneiss which do not appear to contain anomalous geochemical samples, so that the cause of the anomaly may not be strictly lithologic. The western margin anomaly follows the outcrop pattern of the Sangre de Cristo and related faults north of the Great Sand Dunes National Monument, and the Carbonate Mountain anomaly occurs in an area of extensive faulting. These faults may have served as conduits for mineralizing fluids. Gneissic rocks near the western margin of the range are typically extensively sheared and fractured and locally altered to sericite-epidote-quartz rock.

Gold has been found in many drainages within the western margin-Carbonate Mountain area, but rarely in amounts that are detectable by stream geochemistry. As yet undiscovered, moderate tonnage, lowgrade gold deposits formed by hot-water systems moving through faults and fractures may exist in this anomalous area. If a deposit of this type exists, it might be discovered by tracing the many base-metal anomalies to their source.

The Blanca Peak anomalous area which includes nearly all of the study area south of North Zapata Creek contains anomalous copper and tungsten throughout. The northern part of the area also contains anomalous cadmium, molybdenum, and zinc. 


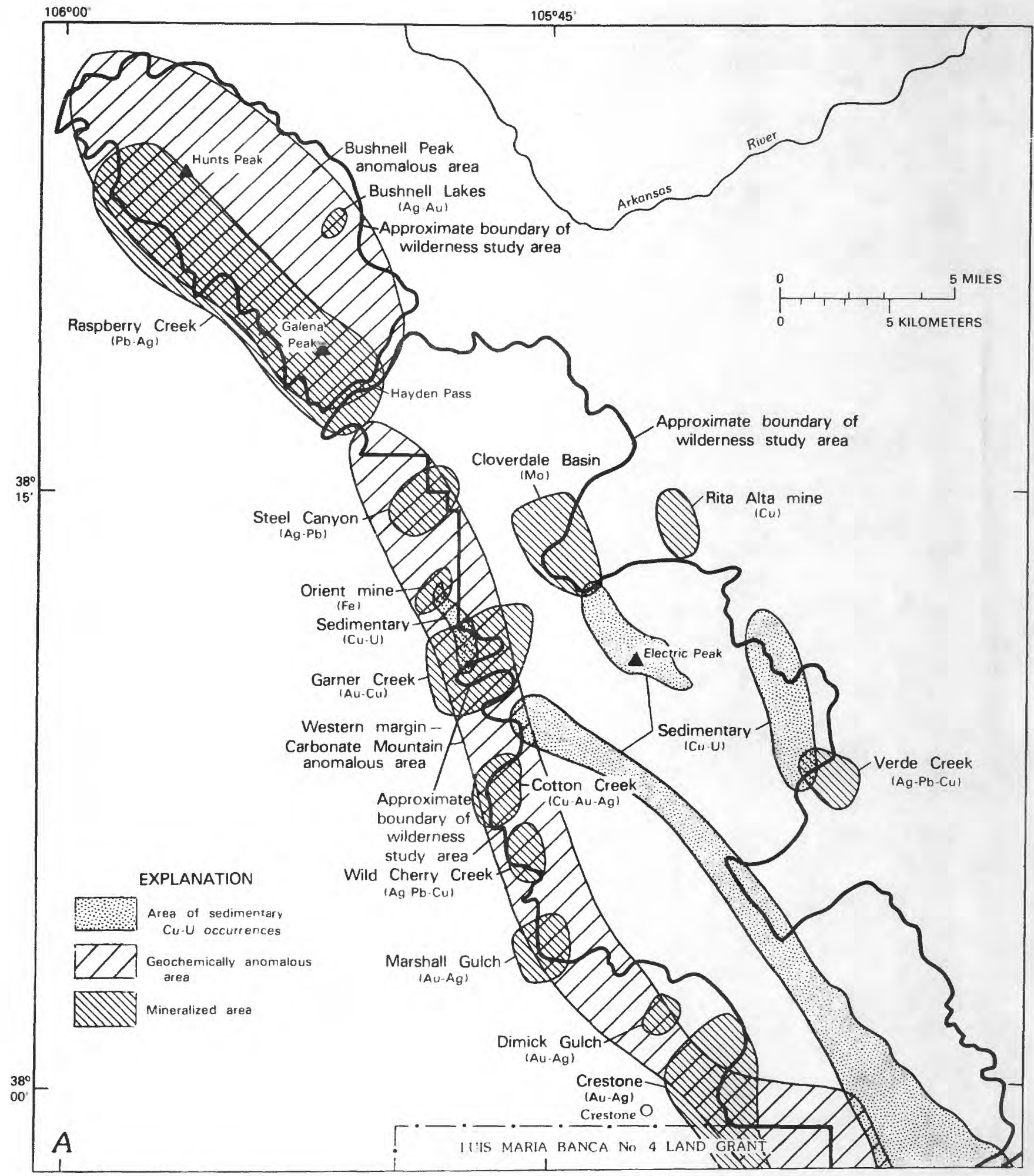

Figure 2.--Mineralized areas and geochemically anomalous areas in the Sangre de Cristo Wilderness Study Area. A, northern half. B, southern half. 


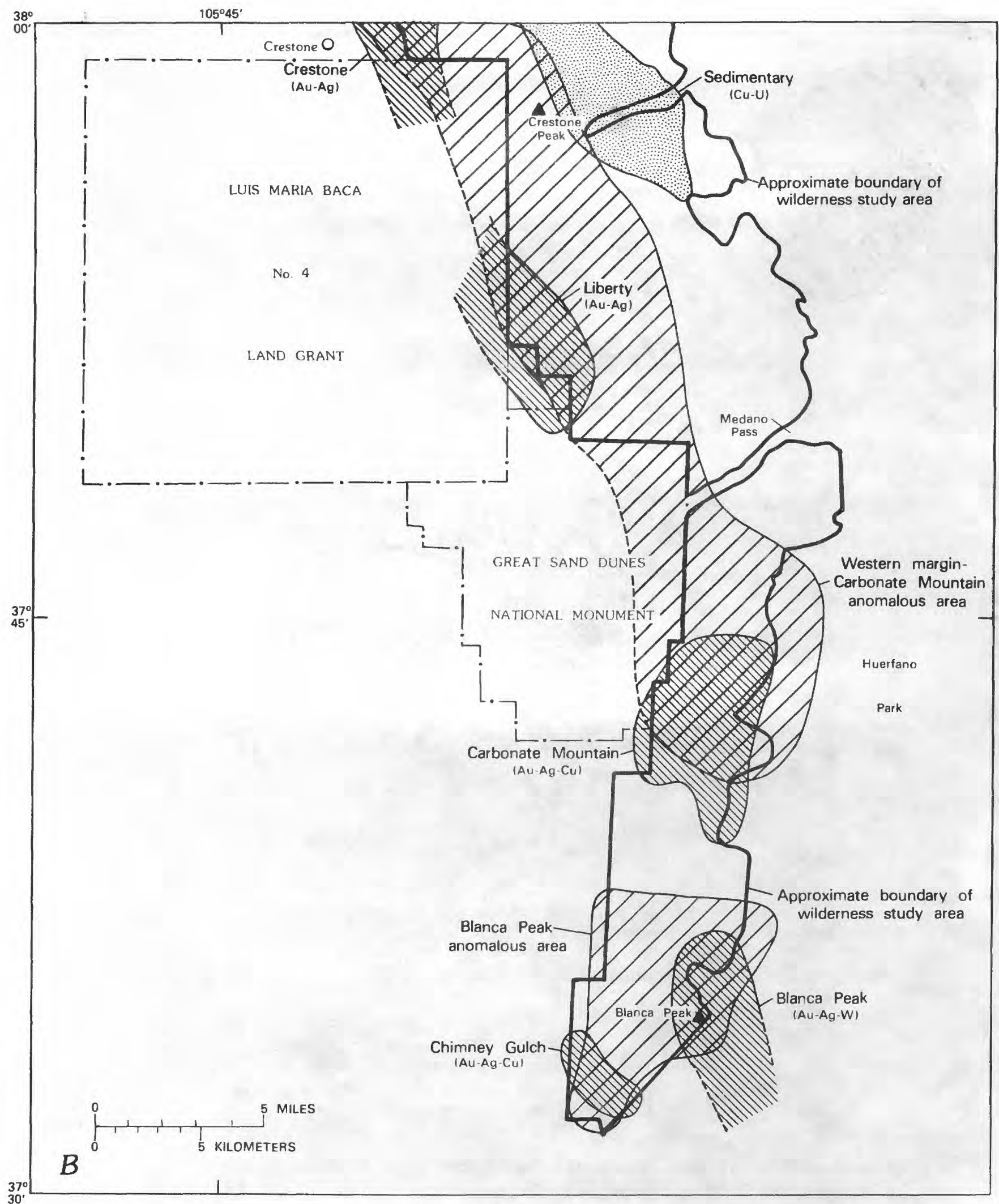

Figure 2.--Continued. 
The upper Huerfano River drainage, which is mostly outside of the WSA, contains anomalous cadmium, copper, lead, molybdenum, tin, tungsten, and zinc.

The anomaly in the Huerfano River drainage is apparently caused by fault-controlled quartz veins at the head of the drainage which contain visible scheelite, pyrite, and copper oxides. Gold and silver which show up in assays of vein material are apparently not in the streams in geochemically detectable amounts. These deposits are described further under the Blanca Peak mineralized area, below. Similar quart $z$ veins in faulted rock occur throughout the Blanca Peak anomalous area and are probably the cause of the broad copper-tungsten anomaly. None of these veins other than the one at the head of the Huerfano River have been found to contain precious metals in more than trace amounts.

In addition to the large areas of geochemical anomalies above, several smaller anomalous areas occur on the eastern side of the study area. Samples from Taylor Creek to Horn Creek east of the divide in the northeast part of the study area are anomalous in copper and weakly anomalous in lead and zinc. This anomalous area and even weaker, similar anomalies which occur along other streams draining upper Paleozoic sediments may be caused by the copper-uranium mineralization described below. There are also scattered localities anomalous in beryllium, copper, lead, and locally cadmium, tin, and zinc which occur along the trace of the Alvarado fault. These anomalies are apparently related to fluids moving along the fault or to the Precambrian rocks uplifted by the fault.

\section{Copper-uranium anomalies}

Mineralized sedimentary rocks containing anomalous concentrations of copper and uranium occur in the lower part of the Sangre de Cristo Formation and the upper part of the Minturn Formation (figs. 2A, B). Mineralized rock occurs as stratiform lenses in carbonaceous limestone, shale, and siltstone beds. The mineralized rock can be distinguished by local accumulations of carbonaceous plant trash, rusty spots of iron oxide after pyrite, and anomalous radioactivity. Blooms of copper and uranium carbonate are rare. Most of the mineralized lenses do not exceed $3 \mathrm{ft}$ in thickness and do not extend more than a few hundred feet along strike, but one mineralized bed near the top of the Minturn Formation has been traced more or less continuously for $8 \mathrm{mi}$ along strike. Analyses of 120 partly weathered samples from outcrops of the mineralized rock show an average (and maximum) metal content of $115 \mathrm{ppm}$ ( 0.8 percent) copper, $28 \mathrm{ppm}$ $(1,300 \mathrm{ppm})$ uranium, $43 \mathrm{ppm}$ (0.7 percent) lead, and 94 ppm $(520 \mathrm{ppm})$ zinc. Concentrations of arsenic (average of $4 \mathrm{ppm}$ and maximum of $26 \mathrm{ppm}$ ) and vanadium (average of $117 \mathrm{ppm}$ and maximum of 1,730 ppm) may be slightly anomalous. No anomalous quantities of silver were found. Weathering and erosion of the mineralized rock are probably responsible for anomalous concentrations of copper, lead, and zinc in the sediments of streams draining outcrops of mineralized lenses.

\section{MINING DISTRICTS AND MINERAIZED AREAS}

Prior to field investigations, a background search was made of published literature, Bureau of Mines files, and files of the Colorado Division of Mines. County courthouse and Bureau of Land Management records were searched for mining claims and oil and gas leases. Mines, prospects, and mineralized areas inside and within $1 \mathrm{mi}$ of the study area were mapped and sampled. Samples were taken from mineralized geologic structures exposed at workings or in outcrop. Samples from inaccessible workings were taken on a grid across the dumps.

A total of 1,310 assay samples were collected; all were fire assayed for gold and silver and spectrographically analyzed for 40 elements. Where the presence of tungsten, copper, lead, and uranium was known or suspected, analyses were performed by appropriate techniques. Complete analytical results are available for public inspection at the Bureau of Mines, Intermountain Field Operations Center, Building 20, Denver Federal Center, Denver, Colorado 80225.

\section{Mining activity}

Mining activity inside the WSA in recent years has been limited to exploration for uranium, molybdenum, copper, and gold. Within the 20 th century, gold has been produced from various properties along the west side of the area, and uranium was produced from a few workings scattered through the area. No mines with significant recorded production are in the study area. The Orient mine, located outside the western boundary of the area, produced iron ore from 1880 to 1931. Although there is no recorded production for the Independant mine, located in the Crestone district outside the western boundary of the area, it reportedly made its two owners millionaires. The Crestone district had several small producing mines prior to 1904 when a Supreme Court decision brought about eviction of all miners from the Baca Land Grant (Parker, 1952, p. 27). None of this production is recorded. Production from other properties and details of mining claims are in Ellis and others (1983).

\section{Mining districts and mineralized areas}

The following mining districts are within the Sangre de Cristo Mountains, in and adjacent to the WSA: Blake (Mirage), Blanca, Bushnell Lakes, Cedar Creek, Cloverdale Basin, Cotton Creek, Crestone, Crestone Needles, Hayden Pass, Hermit Pass, Horn Peak, Liberty (Music), Marble Mountain, Orient, Raspberry Creek, Rita Alta (Spruce Creek), San Isabel, South Rock Creek, Steel Canyon, Verde, West Blanca, and Wild Cherry Creek (Ellis and others, 1983). No boundaries have been defined for any of these districts. Except for references to the part of the Crestone distict on the Baca Land Grant, there will be no further mention of districts. Instead, the study area has been divided into areas of similar mineralization. The mineralized areas from north to south are: (1) Raspberry Creek, (2) Bushnell Lakes, (3) Steel Canyon, (4) Cloverdale Basin, (5) Rita Alta mine, (6) Orient mine, (7) Garner Creek, (8) Cotton Creek, (9) Wild Cherry Creek, (10) Verde Creek, (11) Marshall Gulch, (12) Dimick Gulch, (13) Crestone, (14) Liberty, (15) Carbonate Mountain, (16) Blanca Peak, (17) Chimney Gulch, and (18) sedimentary copper-uranium occurrences (figs. 2A, B). Detailed descriptions of the 
mineralized areas and chemical analyses can be found in Ellis and others (1983).

Raspberry Creek area.-The elongate Raspberry Creek area extends along the west side of the study area from near the north end to Hayden Pass, and from the base to the crest of the range. Small quartz veins, containing galena and chalcopyrite with traces of gold and silver, occur in Precambrian rocks from Hayden Pass to Galena Peak, mostly along the crest of the range. The large number of caved workings along the base of the range, where one dump sample of vuggy quartz and limonitic granitic gneiss contained gold and silver in assay, may have been an attempt to intersect these small veins at depth. Dumps of caved workings near the mouths of Raspberry Creek and Eaglebrook Creek have vuggy quartz vein material, with assays showing gold and silver.

Bushnell Lakes area.-Within the study area, on the east side of the range, Paleozoic limestone has been faulted and altered. Several prospects in the limestone show brecciation and introduction of iron. Assays from these pits show traces of gold and silver. Several prospects are in silicified, serpentenized limestone that contains rare chrysotile asbestos.

Steel Canyon area.-Steel Canyon is just south of Hayden Pass on the west side of the WSA. The workings, which consist of small marble quarries and underground workings on veins in Paleozoic limestone, are all outside the WSA. About $0.5 \mathrm{mi}$ outside the study area boundary, on the ridge south of Steel Canyon, two shafts explore calcite-fluorite-barite veins containing up to $1.0 \mathrm{oz}$ per ton silver, rare galena, and malachite. These veins pinch out in the shallow workings. Two adits, over $0.5 \mathrm{mi}$ apart, follow what could be the same vein. Assays of samples from the western adit show lead, gold, silver, and trace amounts of copper, zinc and antimony. The vein pinches out in the west end of the adit, but the fault persists. Vein material on the hanging wall of the eastern adit is calcite, limonite, and galena. A sample of this vein assayed $10.3 \mathrm{oz}$ per ton silver. This vein might extend into the study area. Quartz vein material assaying $2.5-5.0$ oz per ton silver occurs on the dump of a caved shaft in Precambrian granitic gneiss not far from the western adit.

Cloverdale Basin area.-Cloverdale Basin is mostly outside of the WSA boundary. The Oligocene Rito Alto stock crops out along the crest of the range within the study area. The stock was prospected before 1918 for molybdenum (Worcester, 1918, p. 5253). Further prospecting within the basin and its surroundings in the past several years has met with little success. Contacts of the stock with the surrounding Minturn Formation are: (1) faults with minor alteration, and (2) intrusive contacts with intense, but local thermal alteration and remobilization of iron. Molybdenite occurrences are associated with quartz veins and a granitic dike within the stock, although many samples from other parts of the stock contain trace amounts of molybdenum and copper. Small amounts of gold, silver, and tungsten were also found in assays of samples from the stock. Although anomalous molybdenum shows up in a few stream sediment samples on the flanks of the range from streams draining the Rito Alto stock area, Cloverdale Basin was not found to be geochemically anomalous by this study.
Rito Alto mine.-The Rito Alto mine is about 0.5 mi outside the eastern boundary of the WSA. The mine produced copper, silver, and gold from workings which were inaccessible in 1979 and 1982. Horizontal and high-angle veins of barite, quartz, and chalcopyrite along bedding planes and joints are exposed in an open cut in sandstone and siltstone of the Sangre de Cristo Formation. The mineralization may be related to the Rito Alto stock to the west.

Orient mine.-The Orient mine is outside the western edge of the WSA. The mine produced 1.7 million tons of iron ore (Stone, 1934, p. 317) from an oxidized replacement deposit in sheared Leadville Limestone adjacent to the Sangre de Cristo fault. According to Stone (1934), the ore was limonite after siderite. Sparse barite and chalcopyrite occur throughout the ore body. Gold was reported in some assays (Stone, 1934, p. 325).

Stone's work identified reserves below the main (fifth) level. A sixth level was started, but was never advanced to the remaining ore. This resource is outside the WSA and does not continue along strike into the study area because the Leadville Limestone is cut off by a fault just north of the mine. The Sangre de Cristo fault may have acted as a passageway for the mineralizing fluids. Because the mineral assemblage (barite and chalcopyrite) is the same as that found at the Rito Alto mine and elsewhere around the Rito Alto stock, the stock is a possible source of mineralizing fluids.

Gamer Creek area.-Approximately half of the Garner Creek area (fig. 2.A) is in the study area. The area is composed of small fault blocks. Hot Springs Canyon, the northern part of the area, has three adits in Precambrian granodiorite. Two of these adits explore a small quartz vein with sparse chalcopyrite. The third adit explores a barite vein with minor chalcopyrite. Garner Canyon has a number of small workings on faults in Precambrian granite and Paleozoic quartzite, shale, and sandstone of the Minturn Formation. A brecciated zone in shale exposed in an adit has fillings of limonite, barite, chalcopyrite, and malachite. Some wallrock replacement is evident. Assays show minor silver content in this material. The Rito Alto stock contact zone is exposed in prospects not far up the canyon. Copper, cobalt, and molybdenum are present in most of the samples from Garner Creek. Major Canyon, south of Garner Canyon, has two adits on a brecciated contact between lower Paleozoic limestone and quartzite. Limonite has replaced some of the limestone. Iron content averaged 53 percent in this iron prospect, and gold averaged $0.094 \mathrm{oz}$ per ton.

Cotton Creek area.-Cotton Creek is just south of Major Creek on the west side of the WSA. Chalcopyrite is found disseminated in Precambrian gneiss and granite, along foliation planes in gneiss, in quartz veins, and in quartz-barite veins from Cotton Creek nearly to Wild Cherry Creek. Adits, open cuts, pits, and drill holes were used to explore the deposit. Mining attempts date from about 1900 to the mid1960 's. Silver and gold are present in some samples. The presence of barite and chalcopyrite suggest a possible relationship to mineralization at the Orient mine and the Garner Canyon area. The deposit may be related to the adjacent Sangre de Cristo fault or the Rito Alto stock, or may have been influenced by both. 
Wild Cherry Creek area.-On the west side of the WSA, south of Cotton Creel, quartz veins and faults trending N. $10^{\circ} \mathrm{W}$. to N. $20^{\circ} \mathrm{E}$. are explored by eight adits in Precambrian granite and gneiss inside the study area. On the north side of Wild Cherry Creek, two narrow quartz veins containing galena and sparse chalcopyrite are explored in two adits and a 30-ft shaft. Both veins contain silver averaging $0.6 \mathrm{oz}$ per ton of ore. A lower adit that should have cut both veins is caved. All other structures in the area are nearly barren.

Verde Creek area.-The Verde Creek area is outside the eastern boundary of the WSA. Quartz veins in Precambrian gneiss contain galena, chalcopyrite, and minor barite. Vein trends are uncertain because of inaccessible workings and lack of outcrop. Assays show traces of silver in about half of the samples and gold in a few.

Marshall Gulch area.-On the west side of and within the study area, south of Cedar Creek, shallow workings explore shear zones and quartz veins in Precambrian granite. The structures trend northnorthwest, parallel to the Sangre de Cristo fault. Gold, silver, and copper are present in some samples, but approximately half the samples are barren. A small amount of uraninite occurs in pegmatite (see section on miscellaneous resources) near Rito Aito Creek, just north of Cedar Creek.

Dimick Gulch area.-The Dimick Gulch area is on the west side of the WSA, south of San Isabel Creek. Shallow workings explore a gossan zone in lower Paleozoic limestone and quartzite overlying Precambrian granite on a possible thrust fault. Trace amounts of silver, gold, copper, cobalt, arsenic, molybdenum, and lead were found in many samples from Dimick Gulch.

Crestone area.-The Crestone area is about midway along the west side of the study area. It includes the northern end of the Crestone mining district, the southern two-thirds of which is on the privately owned Baca Land Grant. Oxidized quartz veins containing limonite and pyrite were first worked by Spanish explorers (Parker, 1952, p. 25). The district boomed during the 1880's and $1890^{\prime}$ 's, but a Supreme Court decision granted all mineral rights in the southern part of the district to the owners of the Baca Grant, and by 1904 the miners were removed (Parker, 1952). The northern part of the district, around the town of Crestone, was not as rich and mining activity declined rapidly after 1904. Veins in the district trend north to north-northwest with steep dips and are essentially parallel to the Sangre de Cristo fault. Country rock is Precambrian quartz monzonite. The remaining mineralization consists mostly of unoxidized veins that could not be profitably milled in the 1880's and $1890^{\prime} \mathrm{s}$. In the $1930^{\prime} \mathrm{s}$ the cyanide process was successfully used to extract gold from these veins (Parker, 1952), but World War II curtailed the operation.

Liberty area.-The Liberty area is on the west edge of the WSA, southeast of the Baca Land Grant, and on the north edge of the Great Sand Dunes National Monument. North to northwest-trending faults and quartz veins in Precambrian gneiss contained enough gold and silver to encourage considerable development. Galena, chalcopyrite, and sphalerite are present in one vein in Pole Creek Canyon.
Carbonate Mountain area.-The Carbonate Mountain area is mostly inside the study area south of Mosca Pass and southeast of the Great Sand Dunes National Monument. Prospecting was extensive in Morris and Evans Gulches, adjacent to the national monument. The rocks are a contorted mass of metamorphosed sedimentary rocks probably derived from the Minturn Formation. Copper, gold, and silvex are locally present, but their relationship to structure or rock type is not apparent due to few exposures. The crest of the range, from Mosca Pass south for $7 \mathrm{mi}$, was extensively prospected. Several caved adits are on the east side of the ridge south of Carbonate Mountain. Accessible prospects are on northwesttrending quartz veins in Precambrian gneiss. Gold, silver, copper, and lead occur in some samples.

There are several short adits in Precambrian gneiss and granite near the mouth of North Arrastre Creek. Chalcopyrite is present in an adit which explores a small fault on the north side of the canyon. Samples from this fault and from four dumps across the canyon contain trace amounts of gold. No structural relationship can be established between the various workings because adits on the south side of the canyon are caved, and outcrop on the south side of the canyon is lacking.

Blanca Peak area.-At the southeast end of the study area, fault-controlled quartz veins occur in Precambrian gneissic tonalite and metadiorite in the vicinity of Blanca Peak. One quartz vein in the gneissic tonalite on the northeast side of Blanca Peak strikes about $\mathrm{N} .30^{\circ} \mathrm{W}$. and is exposed for about $2 \mathrm{mi}$. The vein enters the study area, but is hidden under talus and its extent within the study area is unknown. A northern branch of the vein probably also enters the study area. The vein and its main branch have over 3,000 ft of development. Gold and silver are detected in almost every sample, and average $0.1 \mathrm{oz}$ gold per ton and $2.0 \mathrm{oz}$ silver per ton across an average $4-\mathrm{ft}$ mining width. Scheelite, visible under ultraviolet light in many places in the vein, may be separate from and unrelated to the gold and silver. Gold is clearly associated with pyrite. Silver is present in the form of a red-gray mineral. Copper oxides are also common. Other quartz veins on the south and west sides of Blanca Peak contain the same minerals although in lesser amounts.

Chimney Gulch area.-The Chimney Gulch area is mostly inside the WSA at its south end. Workings explore northwest-trending quartz veins and irregular altered zones in Precambrian gneissic tonalite. A few samples contained gold and silver, and several showed copper, cobalt, molybdenum, and bismuth.

Sedimentary copper-uranium areas.-Sedimentary copper and uranium occur scattered over a large part of the study area, in the central part of the Sangre de Cristo Range. Most occurrences are in the upper part of the Minturn and the lower part of the Sangre de Cristo Formations and are located along the crest of the range from Music Pass on the south almost to Hayden Pass on the north. Uranium-mineralized rock is spotty and of low grade. Few prospects give scintillometer readings over 200 counts per second (against a background of 40-60 counts per second). Ninety-eight samples were analyzed fluorimetrically; only eight contained over 100 ppr $\mathrm{U}_{3} \mathrm{O}_{8}$. Copper occurrences are scattered and consist of malachite 
staining and sparse chalcopyrite near fauits and small barite veins with sparse chalcopyrite. Although both copper and uranium occurrences are widely distributed in the upper Paleozoic sedimentary rocks, the occurrences are too small and low grade to be identified as resources.

\section{Miscellaneous resources}

Precambrian pegmatites scattered along the west side of the Sangre de Cristo Range have been worked for uranium (Nelson-Moore and others, 1978), feldspar, and beryl. A little manganese was produced from a fault in Rito Alto Creek; decorative quartz was quarried from a vein near Crestone; veins near Liberty were worked for fluorite. All of these occurrences are small, and currently uneconomical.

Northeast of the study area, at Coaldale, gypsum is being mined from the Minturn Formation. The Minturn beds that are being mined are not known to exist in the WSA. Limestone has been quarried on the northeast side of the study area for use in sugar beet refineries and Colorado Fuel and Iron Corporation's steel mill (Argall, 1949, p. 262). The limestone crops out from Hayden Pass to the Arkansas River. Many claims for limestone were staked within the study area near Hayden Pass, however, substantial amounts are available outside the WSA where there is highway and railroad access.

Bentonite was being mined north of the study area in 1979. The mines were idle in 1982. The bentonite is in Tertiary volcanic rocks which are not present in the WSA. A small quarry near the bentonite mines yielded building stone from a rhyolite tuff of local extent. Prior to the establishment of the Great Sand Dunes National Monument the dunes were placer mined for gold. Part of the gold was in magnetite and not readily recoverable (Siebenthal, 1910, p. 48).

\section{Energy resources}

The Sangre de Cristo fault, which bounds the Sangre de Cristo Mountains on the west, is a component of the Rio Grande rift. Hot springs are not uncommon along the rift. Valley View Hot Springs, just south of the Orient mine is the only known hot springs along the Sangre de Cristo fault. Two known geothermal resource areas are within $2 \mathrm{mi}$ of the study area (fig. 3A). As of November 1982, there were 10 geothermal leases and four geothermal lease applications within $2 \mathrm{mi}$ of the WSA boundary.

As of November 1982, there were 10 oil and gas leases and nine oil and gas lease applications within 2 mi of the study area boundary. Inside the WSA, 60 acres were leased for oil and gas, and 10,600 acres were under oil and gas lease application.

\section{ASSESSMENT OF MINERAL RESOURCE POTENTIAL}

For the purposes of this assessment, a high mineral resource potential is assigned to areas where all geologic conditions and existing data indicate a high probability that large volumes of mineralized rock of potential ore grade and size exist. Moderate mineral resource potential is assigned to areas where some geologic conditions indicative of potential ore grade material are present but where evidence for such ore grade material is less clearcut than in areas of high mineral resource potential. Areas identified as having low mineral resource potential lack either evidence of potentially economic mineralization or geologic conditions that are indicative of such mineralization. Areas which lie outside the WSA were not evaluated for this report unless there was a direct connection with adjacent areas within the study area.

Three areas with potential for metallic mineral resources were delineated within the study area (figs. $3 A, B)$. The three areas are: (1) the Rito Alto stock and vicinity (low to moderate potential; area 1 , fig. $3 \mathrm{~A}),(2)$ a northwest-trending fault zone that extends along most of the western boundary of the study area (moderate potential; areas $2 \mathrm{~A}, \mathrm{~B}$, fig. 3 ), and (3) an area of northwest-trending veins near Blanca Peak (high potential; area 3, fig. 3B). The remainder of the WSA has low potential for metallic mineral resources.

The Rito Alto stock and vicinity (area 1, fig. 3A) contains molybdenum, copper, tungsten, and gold and has low to moderate resource potential for molybdenum. Mineralized areas east and west of the stock may be related to the stock, but are also near rangebounding faults, so that the genetic relationship with the stock is unclear. Accurate assessment of the mineral potential of the stock and vicinity is limited by current lack of understanding of the level of erosion of the stock, and by inability to interpret the depth of mineralization represented by the mineral occurrences there.

The northwest-trending mineralized zone (areas $2 a$ and $b$, figs. 3A, B) follows most of the faulted west side of the Sangre de Cristo Range north of the Great Sand Dumes National Monument. Between areas $2 a$ and $2 \mathrm{~b}$ the zone may pass beneath the dunes, and in area $2 \mathrm{~b}$ it crosses the range. The mineralized zone is broken by covered intervals, but it is interpreted to be more or less continuous. Gold occurs throughout the zone, but the relative abundance of other metals along the zone varies (figs. 2A, B). Anomalous concentrations of metals characterize most streams draining the mineralized zone. Deposits and occurrences of gold, silver, iron, copper, and lead are localized within the zone by faults, shears, and calcareous strata. The most intensely mineralized segment of the zone extends southward from the Orient mine about $10 \mathrm{mi}$, where the faulted west margin of the range intersects a zone of Laramide thrust faults. Precious and base metals occur in this area in many faults and shears. Calcareous strata, which are favorable hosts for replacement deposits, crop out in the mineralized zone from Steel Canyon to Crestone, and locally further south. The iron deposits of the Orient mine, located outside the WSA, replace calcareous rocks. Hot springs (fig. $3 \mathrm{~A}$, Valley View Hot Springs) in the fault zone are a possible indicator of buried hydrothermal activity.

The area of high mineral resource potential near Blanca Peak (area 3, fig. 3B) contains gold-, silver-, and tungsten-bearing quartz veins which are localized along northwest-trending, high-angle fault zones. The only known deposits of probable economic grade lie outside the WSA. However, because the controlling structures continue into the study area and similar mineralized quartz veins are known to exist within the study area, an area of high mineral resource potential 


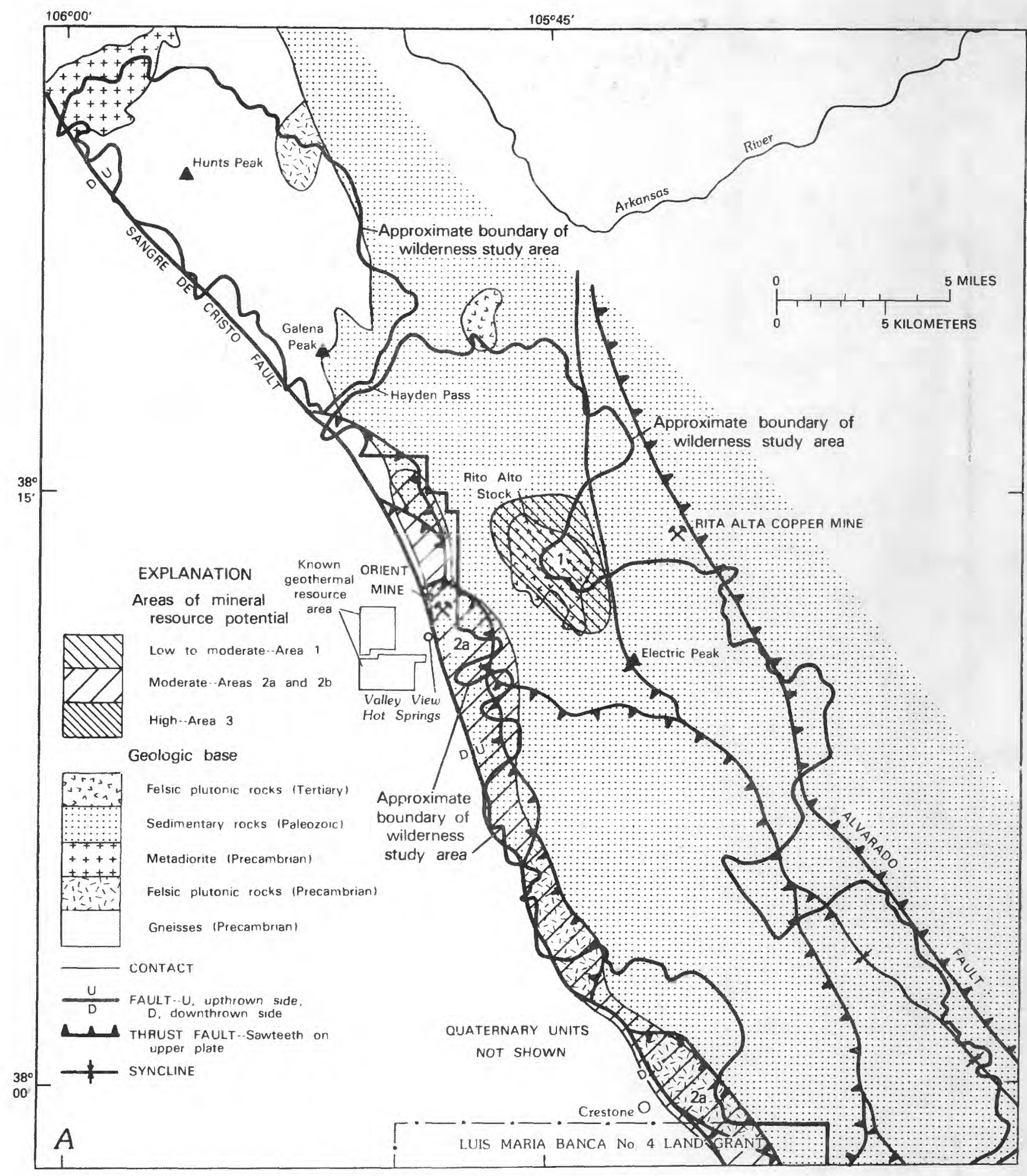

Figure 3.--Generalized geology and areas with mineral resource potential in the Sangre de Cristo Wilderness Study Area. A, northern half. B, southern half. 


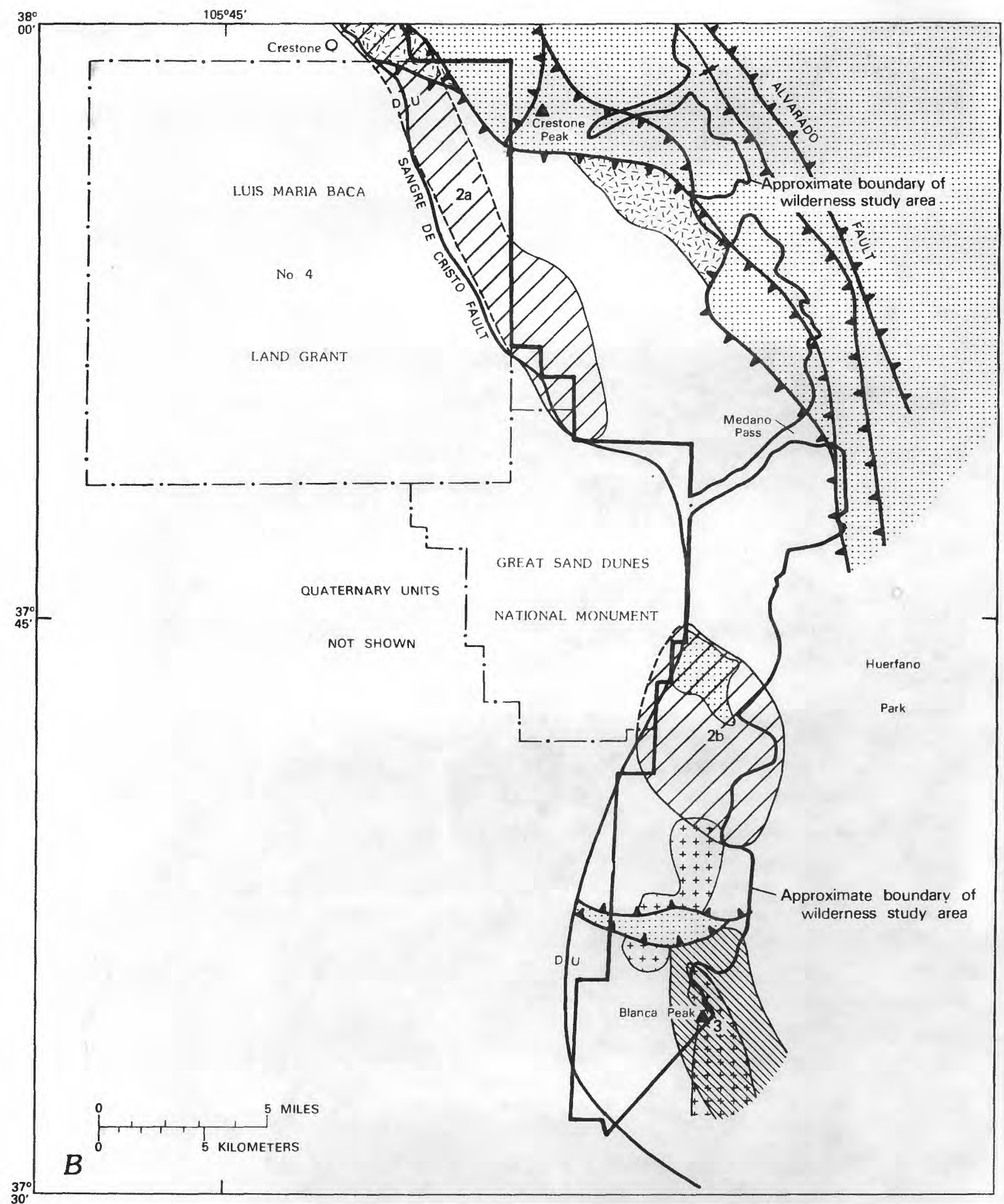

Figure 3.--Continued. 
has been identified. The boundary of area 3 is based on the known extent of gold-silver mineralization and the extent of geochemically anomalous samples.

Low potential for geothermal resources exists in a small part of the WSA southeast of Valley View Hot Springs, along the west side of the range (fig. $3 \mathrm{~A}$ ). Valley View Hot Springs are outside the study area, but smaller hot springs occur along Cotton Creek inside the study area.

Oil and gas potential of the WSA is low. The area is not known to contain favorable host and source rocks for oil and gas, and favorable rocks are judged not present beneath thrusts that traverse the northern half of the study area. Assessment of the potential of the southern half of the study area is difficult because of inadequate knowledge of the structure there. Favorable source and host rocks for oil and gas occur in Huerfano Park, east of the southern half of the study area. Such rocks probably do not extend westward into the study area, but the existence of thrust faults in the adjacent part of the study area leaves open the remote possibility that favorable strata for oil and gas lie beneath the thrusts.

Limestone is present in the WSA from Hayden Pass northward. More convenient limestone resources are present outside of the study area near the Arkansas River.

\section{REFERENCES}

Argall, G. O., Jr., 1949, Industrial minerals of Colorado: Colorado School of Mines Quarterly, v. 44, no. 2, 477 p.

Ellis, C. E., Hannigan, B. Jo, and Thompson, J. R., 1983, Mineral investigation of the Sangre de Cristo Wilderness Study Area, Alamosa, Custer, Fremont, Huerfano, and Saguache Counties,
Colorado: U.S. Bureau of Mines Open-File Report MLA 65-83, 190 p.

Grimes, D. J., and Marranzino, A. P., 1968, Directcurrent arc and alternating-current spark emission spectrographic field methods for the semiquantitative analysis of geologic materials: U.S. Geological Survey Circular 591, 6 p.

Johnson, B. R., Lindsey, D. A., Bruce, R. M., and Soulliere, S. Jo, 1984, Reconnaissance geologic map of the Sangre de Cristo Wilderness Study Area, south-central Colorado: U.S. Geological Survey Miscellaneous Field Studies Map MF$1635-\mathrm{B}$, scale $1: 62,500$.

Lindsey, D. A., Johnson, B. R., and Andriessen, P. A. M., 1983, Laramide and Neogene structure of the northern Sangre de Cristo Range, southcentral Colorado, in Lowell, J., ed., Rocky Mountain foreland basins and uplifts: Rocky Mountain Association of Geologists, Symposium, Denver, Colorado, p. 219-228.

Nelson-Moore, J. L., Collins, D. B., and Hornbaker, A. L., 1978, Radioactive mineral occurrences of Colorado: Colorado Geological Survey Bulletin 40, 1054 p.

Parker, C. O., Jr., 1952, A history of gold mining in the Sangre de Cristo's: Mines Magazine, v. 42, no. 5 , p. 25-27.

Siebenthal, C. E., 1910, Geology and water resources of the San Luis Valley, Colorado: U.S. Geological Survey Water Supply Paper 240, 128 p.

Stone, J. Bo, 1934, Limonite deposits of the Orient Mine, Colorado: Economic Geology, v. 29, no. 4, p. 317-329.

Worcester, P. G., 1918, Molybdenum deposits of Colorado: Colorado Geological Survey Bulletin $14,131 \mathrm{p}$. 
: 